\title{
Editorial
}

\section{HIRA Research를 창간하며}

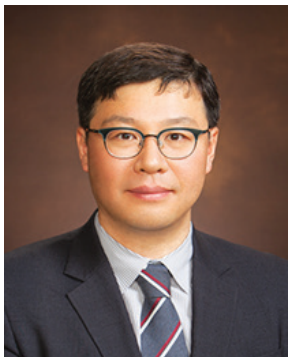

2021년 5월 건강보험심사평가원은 전문학술지 'HIRA Research'의 창간호를 발간 하게 되었습니다. 2007년부터 발간해 오던 정기간행물 ‘HIRA 정책동향’을 전문학술 지로 확대 개편하는 것입니다. 2020년 8월 제가 건강보험심사평가원 심사평가연구소장 으로 취임한 이후 ‘HIRA Research’ 창간 작업을 시작했습니다. 가장 큰 이유는 건강 보험 관련 정책과 이슈를 전문적으로 다루는 학술지가 없다는 것이었습니다. 물론 'HIRA 정책동향이 있기는 했지만 건강보험과 관련된 다양한 이해당사자의 목소리를 담아내는 데에는 한계가 있었습니다. 또한 전문학술지가 아니기 때문에 게재되는 글의 전문성과 중립성을 담보할 수 없었고, 외부에서는 심사평가원의 기관지라는 인식이 강했습니다. 이러한 이유로 'HIRA 정책동향'을 전문학술지로 개편하기로 결정했습니다.

우리 학술지는 의료계, 학계, 시민단체, 정부 등 다양한 현장의 목소리를 반영할 것입니다. 따라서 원저 (original article), 종설(review article), 견해(perspective), 서신(letter), 의견(opinion) 뿐만 아니라 수필 등 다양한 형태의 논문 투고가 가능합니다. 이를 통해 가능한 한 다양한 분야의 시각을 통해 의견을 나누고 토론할 수 있는 학술적 공론의 장을 만들겠습니다. 학술지 창간을 위해 지난해부터 여러 가지 준비를 거쳤습니다. 먼저 심사 평가원 직원 대상 학술지 명칭 공모전을 통해 학술지의 이름부터 정했습니다. 또한 학술지 편집위원회를 구성하 였고 학술지 운영지침과 논문투고 매뉴얼을 만들었습니다. 뿐만 아니라 학술 성과와 가치를 확산하기 위한 전용 홈페이지를 개설하였고, 외부 연구자의 투고를 적극 지원하기 위하여 홈페이지에 온라인 논문투고 - 심사시스템을 구축하였습니다. 마지막으로, 전문학술지 형태를 갖추고자 책자 표지와 내지 디자인을 새롭게 구성하였습니다. 이 과정에서 많은 노력을 해주신 편집위원 및 심사평가연구소 직원 여러분께 감사의 뜻을 전합니다.

특히 부편집위원장으로서 많은 도움을 주신 함명일 교수님과 최윤정 박사님, 창간 작업의 총괄을 맡아주신 조회규 실장님과 조향숙 부장님, 실무자로서 고생해주신 김정림 박사님과 신양준 주임연구원에게 깊은 감사의 말씀을 드립니다. 우리 학술지는 앞으로도 현장의 다양한 의견을 수렴하고 학술적 논의를 거치는 과정 속에서, 각 분야가 소통하며 정책을 수립해나갈 수 있는 학술 문화를 조성하겠습니다. 이 창간호가 보건의료 환경 변화에 대응하는 건강보험 정책 수립을 위한 공론의 장을 만드는 계기가 될 수 있길 바랍니다. 이 창간호가 나오기까지 도움을 주신 모든 분들에게 다시 한 번 감사의 말씀을 드립니다.

2021년 5월 31일 HIRA Research 편집위원장 이 진 용

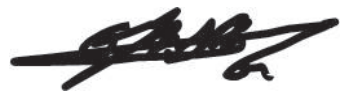

